【論文】

$$
\begin{gathered}
\text { ディスポーザブルライターを指標とした } \\
\text { 海岸漂着ごみのモニタリング }
\end{gathered}
$$

藤枝繁*・小島 あずさ ${ }^{* *}$ ・兼 広 春 之 ${ }^{* * *}$

【要 旨】 全国のベ 120 海岸から収集された 6,609 本のディスポーザブルライターを指標として, 国内 海岸に漂着する海洋ごみの流出地を推定した。流出地・流出国の判別は, ライターのタンク表面の印刷 文字, タンク底面の刻印記号, タンク形状によった。中国ライターの割合は, 沖縄県与那国島から鹿児 島県屋久島までの東シナ海沿岸で最も高く 5 割を越え, 日本海沿岸では山形県まで 1 ～ 2 割を占めた。 韓国ライターの割合は, 沖縄県から九州西岸までの東シナ海沿岸では約 1 割で太平洋沿岸ではほとんど 収集されなかったが，日本海の島根県から福井県では 5 割を越えた。日本ライターは，全国で収集され， 特に四国以北の本州太平洋沿岸, 北海道, 東京湾, 瀬戸内海で 9 割以上を占めた。漂着ライターの流出 地は, 漂着地周辺の内陸部や沿岸部, 中国浙江省・広東省の沿岸部, 台湾・韓国の全域であり, ライ ターを指標とすることにより, 海洋ごみの漂着地と流出地の関係が明らかにされた。

キーワード: 漂着物, 流出起源, ライター, 海洋ごみ, モニタリング

\section{1. 緒}

プラスチック生産量がここ 30 年で急激に増加する中, 近年その廃棄物が海洋に流出し, 海岸に漂着散乱するよ うになってきた。特に沖縄県八重山諸島から奄美諸島の 東シナ海沿岸や日本海沿岸には, 中国, 韓国, ロシアな どの日本周辺の大陸諸国から流出した様々なごみが大量 に漂着している1)。これら大陸から流れ着く海洋ごみは, 越境ごみと呼ばれ，国境を越えた環境污染問題として注 目されるようになってきたが, その流出地や影響範囲と いった情報については，いまだ明らかにされていない。 一方では, 北太平洋を生息域とするコアホウドリが誤食 したディスポーザブルライターの半数以上が日本起源で あったことから²), 太平洋という視点で考えれば，日本 も主要な海洋ごみ流出国となっている。よってプラス

原稿受付 2005.3.14 原稿受理 2005.11. 4

* 鹿児島大学水産学部

** JEAN・クリーンアップ全国事務局

*** 東京海洋大学海洋科学部海洋環境学科

連絡先 : ₹ 890-0056 鹿児島市下荒田 $4-50-20$ 鹿児島大学水産学部環境情報科学講座 藤枝 繁 E-mail : fujieda@fish.kagoshima-u.ac.jp
チックを中心とした海洋ごみ問題は, 日本を含め大陸諸 国におけるプラスチック大量消費時代の到来により, 地 球規模の環境污染問題の一つになったといっても過言で はない。複雑な原因体系を持ち, 継続的に発生し続ける

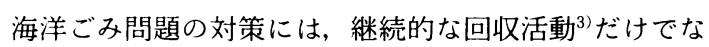
く, 同時に発生抑制策についても広域で考えていかねば ならない。そのためにはまず, 東アジアを起源とする海 洋ごみの現状と起源を把握し，さらには継続的なモニ夕 リング手法を構築して海洋ごみに対する監視体制を整え ることが必要である。

これまで指標漂着物を用いた研究は, 海岸漂着ごみの 全量的変化を追う上で, 特定品目の量的経年変化を調査 した研究や4), 海岸漂着ごみの発生源を求めるために流 出地情報を持つディスポーザブルライター2.5-7), プラス チックボトル ${ }^{5,7)}$, 注射器6,7 および名刺 ${ }^{7)}$ といった特定品 目の収集研究が行われてきた。今回指標に使用したディ スポーザブルライターによる海洋ごみの流出地を推定す る研究は, 1993 年京都府の丹後半島で始まった5)。ここ では現在でも定期的な収集調查が行われており, 定点に おける越境ごみの経年変化を追跡している ${ }^{6)}$ 。一方, 藤 枝は, 同じ手法を用いて 1998 年に鹿児島県薩摩半島西 岸に大量漂着したごみの流出起源を調査し, 中国華南, 
華東地方，台湾抢よび日本が，今回の大量漂着ごみの主 な流出地であることを明らかにした7)。さらに藤枝は, 1999 年以降, 調査範囲を広げ，奄美大島加ら対馬まで の九州西岸海岸における漂着ライターの流出国の構成特 性と流出地について調査し, 特に越境ごみについては, 奄美大島では中国（台湾を含む）の影響を受けるが，対 馬では中国に加え韓国の影響を強く受けることを明らか にした2)。

そこで本研究では, 全国の海岸に漂着する海洋ごみの 流出国・流出地书よびその影響範囲を明らかにすること を目的に，ディスポーザブルライターを指標漂着物とし た全国規模のモニタリング手法について検討した。本報 では， 2003 年 8 月から 2004 年 5 月までの第一期調査の 結果，特に流出地と漂着地に関する結果について報告す る。

\section{2. 調 査 方 法}

\section{1 ディスポーザブルライターの指標としての特性}

今回指標として用いたディスポーザブルライター（以 下ライターと称する）は，夕バコの火付け道具として愛 煙家を中心に広く普及した商品であり, 強固な中空構造
から海岸にも比較的多く漂着している。また小型で派手 なタンク色を持つことから，海岸で発見されやすく，収 集作業や運搬が容易であるという特徵を持つ。さらに夕 ンク底面に刻印された記号から消費製造国（流出国）を 判別することができるだけでなく，図 1 に示すように夕 ンク表面に印刷されている広告等の文字情報加ら消費地 まで判別できる特徴を持つ2)。本研究では, 漂着ライ 夕一が運搬されずに消費地で廃棄されたものと仮定し，

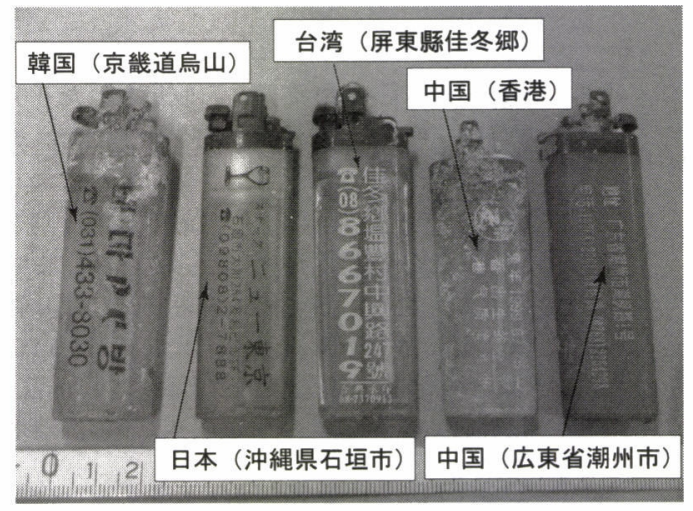

図 1 指標漂着物として使用したディスポーザブルライ 夕ー

表 1 調査結果概要（2003. $8 ＼mathrm{~ 2004 . ~} 5$ ）

\begin{tabular}{|c|c|c|c|c|c|c|c|c|c|c|c|c|}
\hline 海域区分 & 海岸地区名 & $\begin{array}{c}\text { のべ } \\
\text { 海岸数 }\end{array}$ & 海岸数 & $\begin{array}{c}\text { 調查時間 } \\
\text { (分) }\end{array}$ & $\begin{array}{c}\text { 調査員数 } \\
\text { (人) }\end{array}$ & $\begin{array}{c}\text { 調查距離 } \\
\text { (m) }\end{array}$ & $\begin{array}{c}\text { 日本 } \\
\text { ライター }\end{array}$ & $\begin{array}{c}\text { 韓国 } \\
\text { ライター }\end{array}$ & $\begin{array}{c}\text { 採取本数 } \\
\text { 中国・台湾 } \\
\text { ライター }\end{array}$ & その他 & 不明 & 総計 \\
\hline \multirow[t]{5}{*}{ 東シナ海 } & 与那国島 & 11 & 2 & 1,410 & 19 & 10,250 & 178 & 45 & 290 & 16 & 224 & 753 \\
\hline & 石垣島 & 8 & 8 & 605 & 18 & 9,300 & 104 & 32 & 206 & 9 & 127 & 478 \\
\hline & 沖縄島 & 5 & 5 & 135 & 20 & 2,325 & 32 & 13 & 47 & 2 & 31 & 125 \\
\hline & 屋久島 & 1 & 1 & 90 & 1 & 2,300 & 4 & 1 & 5 & 1 & 4 & 15 \\
\hline & 鹿児島西岸 & 12 & 3 & 755 & 84 & 17,300 & 234 & 27 & 69 & 7 & 67 & 404 \\
\hline \multirow[t]{8}{*}{ 日本海 } & 長崎 & 4 & 4 & 140 & 10 & 470 & 40 & 5 & 12 & 3 & 15 & 75 \\
\hline & 福岡 & 6 & 5 & 760 & 10 & 11,850 & 339 & 118 & 101 & 11 & 139 & 708 \\
\hline & 島根 & 5 & 4 & 480 & 5 & 4,000 & 38 & 75 & 24 & 1 & 26 & 164 \\
\hline & 京都 & 6 & 4 & 380 & 7 & 6,420 & 94 & 134 & 62 & 3 & 50 & 343 \\
\hline & 福井 & 2 & 2 & 110 & 2 & 2,800 & 44 & 90 & 17 & 0 & 22 & 173 \\
\hline & 新潟 & 3 & 3 & 180 & 4 & 400 & 165 & 31 & 22 & 9 & 29 & 256 \\
\hline & 山形, & 2 & 2 & 160 & 4 & 1,300 & 364 & 150 & 92 & 11 & 141 & 758 \\
\hline & 石狩（北海道） & 1 & 1 & 60 & 1 & 300 & 54 & 0 & 1 & 4 & 8 & 67 \\
\hline \multirow[t]{8}{*}{ 太平洋 } & 鹿児島東岸 & 5 & 2 & 170 & 7 & 1,100 & 65 & 1 & 38 & 0 & 36 & 140 \\
\hline & 高知 & 8 & 8 & 780 & 8 & 6,950 & 314 & 5 & 37 & 9 & 59 & 424 \\
\hline & 和歌山 & 1 & 1 & 50 & 1 & 300 & 45 & 0 & 3 & 1 & 2 & 51 \\
\hline & 東海（愛知・静岡） & 6 & 5 & 435 & 12 & 8,700 & 184 & 2 & 20 & 7 & 30 & 243 \\
\hline & 茨城 & 1 & 1 & 110 & 1 & 2,500 & 182 & 7 & 23 & 6 & 14 & 232 \\
\hline & 宮城 & 2 & 2 & 57 & 11 & 800 & 43 & 0 & 2 & 1 & 1 & 47 \\
\hline & 十勝（北海道） & 8 & 8 & 1,890 & 21 & 80,650 & 234 & 2 & 9 & 8 & 25 & 278 \\
\hline & 小笠原諸島 & 4 & 3 & 480 & 23 & 1,000 & 72 & 10 & 47 & 2 & 35 & 166 \\
\hline 内湾域・ & 有明海 & 1 & 1 & 120 & 233 & 500 & 69 & 0 & 0 & 0 & 7 & 76 \\
\hline \multirow[t]{4}{*}{ オホーツク海 } & 瀬戸内海 & 6 & 6 & 180 & 10 & 1,800 & 219 & 0 & 7 & 4 & 25 & 255 \\
\hline & 伊勢湾 & 1 & 1 & 60 & 10 & 300 & 34 & 0 & 4 & 1 & 5 & 44 \\
\hline & 東京湾 & 9 & 8 & 650 & 12 & 9,350 & 260 & 0 & 12 & 10 & 27 & 309 \\
\hline & 網走（北海道） & 2 & 2 & 60 & 4 & 1,600 & 19 & 0 & 0 & 0 & 6 & 25 \\
\hline 計 & & 120 & 92 & 10,307 & 538 & 184,565 & 3,430 & 748 & 1,150 & 126 & 1,155 & 6,609 \\
\hline
\end{tabular}


文字情報から得られた消費地名を流出地と定義した。

\section{2 漂着ライターの収集方法および調査期間}

漂着ライターの収集は, 全国の海岸を網羅するため, JEAN・クリーンアップ全国事務局が主催する「国際海 岸クリーンアップキャンペーン」3) に参加している全国 のキャプテンと呼ばれる会場企画責任者および漂着物学 会に所属する全国の海岸漂着物収集家に, 各会報, イン ターネットホームページ，メーリングリストを通じて依 頼した。海岸で拾ったライターは, 収集日時, 海岸名, 調查距離, 調查時間および海岸の状況を記入したデー夕 シートとともに郵送してむらい, 藤枝が分類を行った。 今回分類したライターは, 2003 年 8 月から 2004 年 5 月 までに収集されたものであり, 都道府県を基準とした 26 地区で集計した。各地区別の収集本数, 海岸数等の 調査結果概要を表 1 に示す。

\section{3 漂着ライターの分類方法}

流出地の分類は, 図 1 に示すタンク表面に印刷された 店舗等の住所または電話市外局番を利用し, 店舗名と電 話番号（市外局番なし）のみの場合は, インターネット の電話帳を利用して住所を検索した。また流出国の分類 は, 図 2 に示すようにタンク表面に印刷された文字情報, タンク底面・金属風防に刻印された記号, シール位置沶 よびタンク形状から判別し, 中国, 台湾, 韓国, 日本の 4 つの国之地域に分類した。以下，これらを中国ライ 夕一, 台湾ライター, 韓国ライター, 日本ライターと呼 ふi。

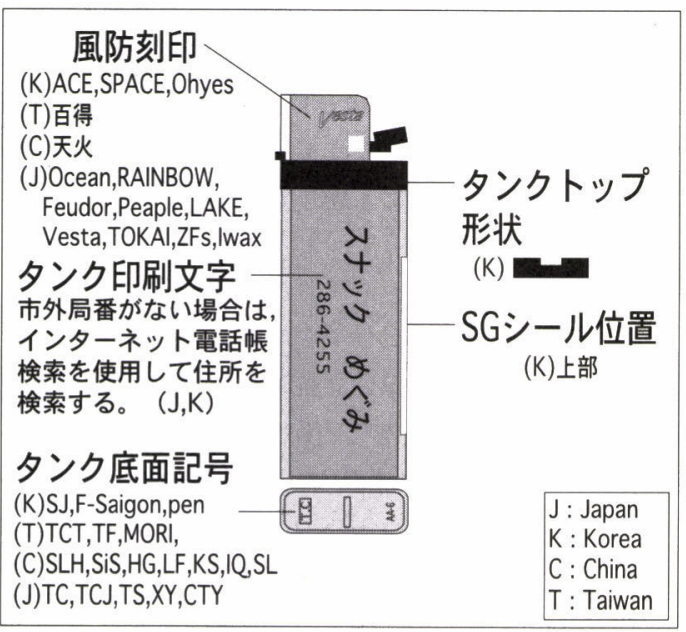

図 2 ライターの分類方法の一例

\section{3. 結果}

今回の調査では, のべ 120 海岸, 重複を除けば 92 海岸 から，6,609 本のライターが収集された。調查協力者数 は 26 名であり, 最多収集者は, 沖縄県与那国島在住の 女性で 694 本, 続いて福剛県在住の男性で 683 本であっ た。また収集海岸は 23 都道府県におよび, 最も収集量 が多かった都道府県は, 沖縄県で 1,356 本, 続いて山形 県 758 本, 福岡県 708 本, 鹿児島県 559 本, 高知県 424 本となった。流出国 (日本, 韓国, 中国) の判明率は総 収集本数の $79.8 \%$ であり,また流出地の判明率は総収 集本数の $10.0 \%$ であった。

\section{1 漂着地域別流出国}

各地に求ける日本, 韓国, 中国（台湾を含む）ライ 夕ーの割合を図 3 に示す。なお流出国の分類の段階では, 中国と台湾を判別できないものもあり，ここでは中国に 台湾を含めて示す。まず東シナ海から日本海に沿った海 岸について見ると, 中国ライターの割合は, 沖縄県与那 国島から鹿児島県屋久島までの東シナ海沿岸で最も高く 5 割を越え, 九州西岸で 2 割台に減少した。九州北部以 北の日本海海岸では, 1 2 割を占め, 山形県海岸でむ 1 割を越えた。一方韓国ライタ一の割合は, 沖縄県から 九州西岸まで約 1 割であったが, 福岡県では 2 割を越え, 島根県から福井県までの日本海中央部海岸では, 日本ラ イターの割合と逆転し 5 割を越えた。中国および韓国ラ イターとも山形県海岸まで達していたが, 北海道石狩地 方ではほとんど見られなかった。白本ライターの割合は, 沖縄から九州西岸にかけて北上するに従い増加したが, 日本海中央部沿岸では韓国ライターの割合の増加により 3 割まで咸少した。新潟県以北では, 中国および韓国ラ イターの割合の減少により再び増加し, 北海道石狩地方 ではそのほとんよ゙を占めた。

次に東シナ海加ら平洋に沿って見てみると, 中国ラ イターの割合は, 九州から四国の間で急激に減少し, 高 知県以北では 1 割を切った。また韓国ライターも九州南 岸以東ではほとんど含まれなかったことから，四国以北 の本州太平洋沿岸では, 日本ライターの割合が 9 割以上 を占めた。なお小笠原諸島では, 日本, 韓国, 台湾, 中 国ライターが収集されたが，日本ライターが半数以上を 占め, 八重山・沖縄地方とはまた異なる構成割合となっ た。その他, 有明海, 瀬戸内海, 伊勢湾, 東京湾などの 内湾および北海道網走地方 (オホーック海) では日本ラ イターが主であった。 


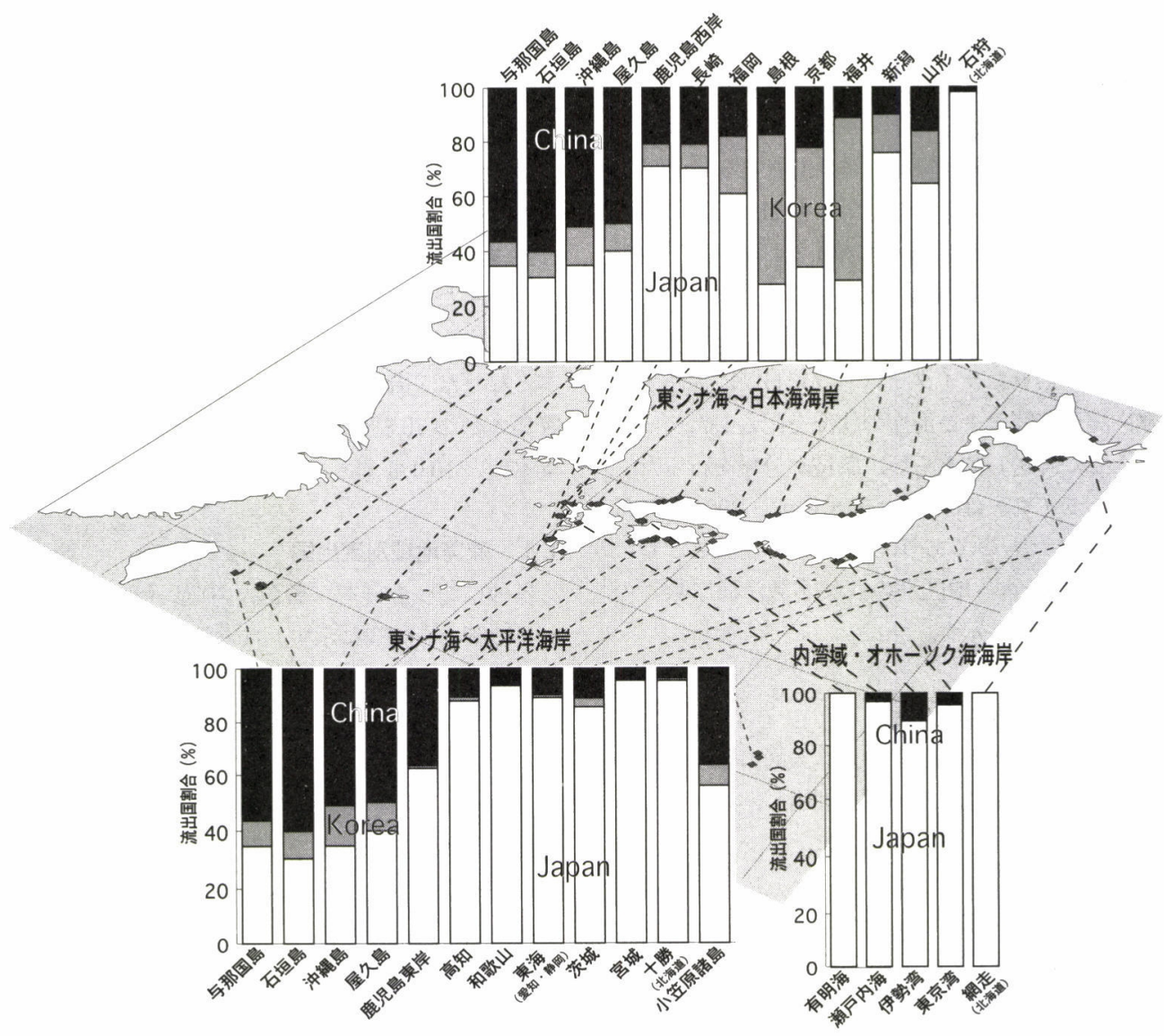

図 3 指標漂着物収集地点と漂着地域別流出国（日本, 韓国, 中国（台湾含む））割合

\section{2 漂着ライターの流出地}

漂着ライターからは流出国だけではなく, 流出地まで 判別することができる。代表的な 7 漂着地域（日本海側 (山形県, 新潟県, 福岡県), 太平洋側 (北海道十勝地方, 茨城県), 内湾域 (東京湾, 瀬戸内海) ) における漂着ラ イターの流出地の分布を図 4 に示す。漂着ライターの流 出地は, 漂着地を中心とした国内内陸部抢よび沿岸部の 広い範囲にわたっていた。山形, 新潟, 茨城の各県では, それぞれ最上川，信濃川，那珂川といった一級河川の流 域都市を起源とするものが多数見られた。

次に図 4 とは逆に, 漂着ライターの流出地（韓国, 中 国，台湾）に対する漂着地の分布を図 5 に示す。中国か ら流出したライターの多くは, 広東省, 浙江省を起源と するものであり, 渤海や黄海周辺起源のものはほ上んど 見られなかった。漂着本数は八重山, 沖縄島海岸で少な く, 日本海海岸に多かった。一方, 台湾から流出したラ イターは, その半数以上が八重山, 沖縄海岸に漂着した。 小笠原諸島では中国ライターよりも台湾ライターの流出
地の判明数が多かった。また中国・台湾ライターは, 太 平洋海岸に比べ日本海海岸に多く, 山形県海岸にまで達 していたが，太平洋側では房総半島以北にはほとんど到 達していなかった。韓国西部を起源とするライターは, 半数が八重山海岸に, またその半数が日本海海岸に漂着 した。一方韓国南西部および南東部を起源とするライ ターは, 主に日本海海岸に漂着し, 一部は八重山, 沖縄 海岸および太平洋海岸にも達していた。

\section{4. 考察}

これまでライターを用いて海洋ごみの流出国, 流出地 を推定した調查は, 京都 ${ }^{5)}$, 山口・島根・新潟・沖縄・ 北海道 ${ }^{6)}$, 福岡 ${ }^{8}$, 薩摩半島 ${ }^{7}$ 㧍よび奄美大島・種子島・ 吹上浜・五島・対馬・ミッドウェー環礁2)などで行われ てきた。しかしこれらは, 特定地点むしくは狭いエリア を対象としていたため, 図 4 のような漂着地から見た流 出地という一方向の情報を得るだけに留まった。今回の 

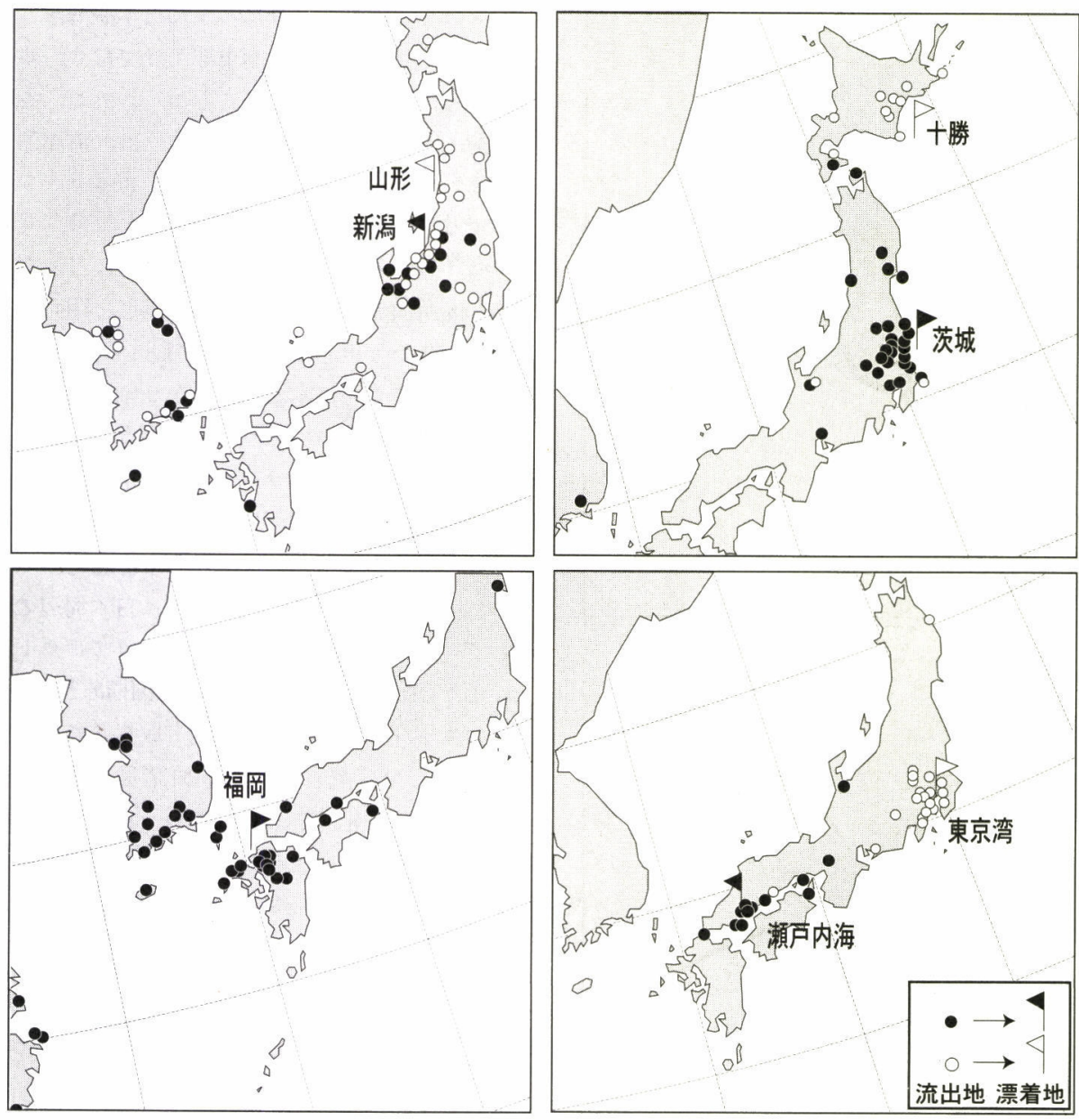

図 4 漂着地から見た指標漂着物（ライター）の流出地

調査では, 全国の漂着物収集家等に収集を依頼すること により，短期間に数量，範囲とも十分な試料を得ること ができ, 図 5 に示したような流出地から見た漂着地を得 ることにより，その影響範囲を知ることができた。これ はライターの小型で発見しやすいといった外形的な特徵 と広く各地で使用されているという大衆性に加え, ロー カル情報の保有といった特徵による。なお今回の調查に おける流出国の判別率は, 全体で $79.8 \%$ となり, 九州 西岸での過去の結果 $(67.8 \sim 82.7 \%)^{2)}$ と比較しても同 程度の結果が得られた。また流出地の判明率は全体で 10.0\%となり，中国のみを対象にした 1998 年の薩摩半 島の結果の $15.0 \%$ には劣るものの ${ }^{7)}, 3$ 力国 1 地域を対 象としたものでは九州西岸での過去の結果 （5.6〜 12.9 $\%)^{2)}$ と比較してここでも同程度の結果を得た。

今回の調査では, 対象地域を全国としたことから, 図 5 に示すような流出地から見た影響範囲を知ることがで きた。この結果を用いて日本周辺海岸に漂着する海洋ご
みの起源を推定すると, 東シナ海南部の沖縄から鹿児島 県南部を中心に大量に漂着している中国系ごみは，主に 中国大陸を起源とした越境ごみであり，八重山諸島に漂 着する中国系ごみは, 台湾を起源とした越境ごみである といえる。また両者を起源とするごみは，太平洋では小 笠原諸島, 日本海では山形県海岸まで漂着するともいえ る。このような結果は, 山口 ${ }^{1)}$ が全国の海岸で行った複 数品目による漂着ごみの流出国調査の結果とほぼ一致す る。また日本海中央部海岸は, 韓国を起源とした越境ご みの影響を強く受けることも同結果と一致した。一方, 日本海における韓国ライターの構成割合の特徵は, 東山 高等学校地学部 ${ }^{6}$ が 1997 年から 1998 年にかけて山口県 下関市, 島根県仁摩町, 京都府網野町, 新潟県新潟市で 行ったライターによる流出国調査の結果とほぼ一致した。 さらに本結果では, 流出地に関する情報をより多く集め ることができたことから，八重山・沖縄海岸に漂着する 韓国を起源とするごみは，主に韓国西部を起源としたも 

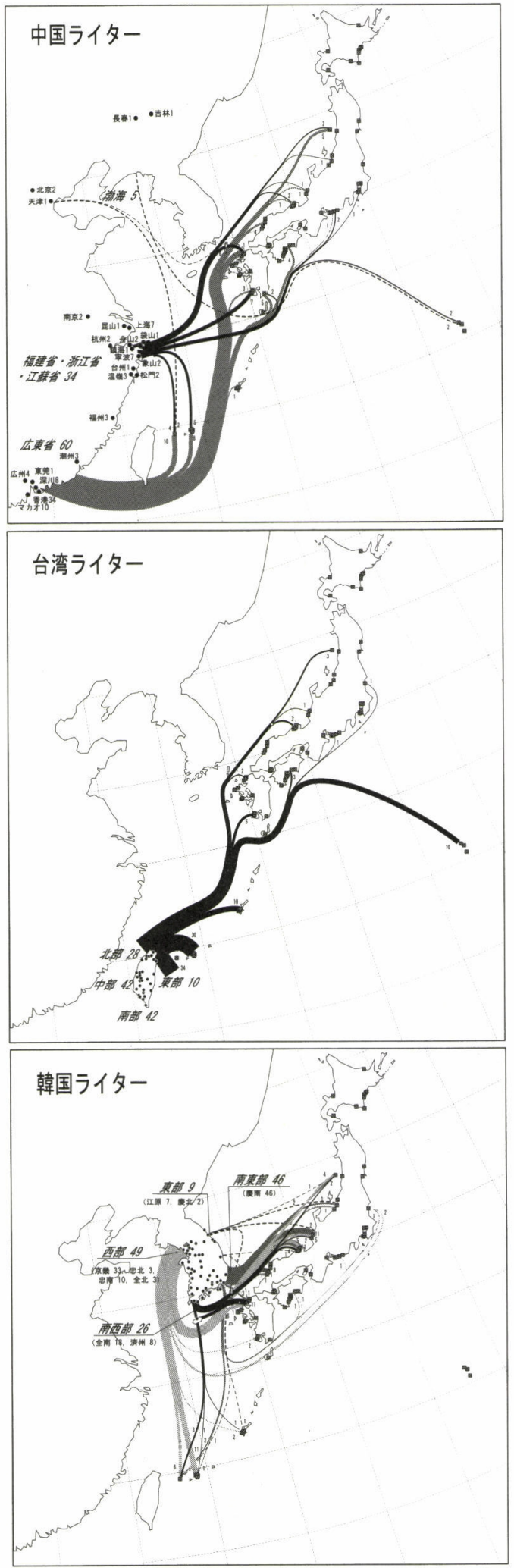

図 5 流出国・地域から見た指標漂着物（ライター）の 漂着地
のであることが示された。また日本海海岸には，日本海 に面した韓国南西部や南東部だけでなく, 韓国西部を起 源としたものも漂着することが示された。このように流 出国・流出地情報を持つライターは, 海岸漂着物の流出 起源を探る有効な指標であるといえよう。

一方，この手法では，越境ごみだけでなく，国内起源 の海洋ごみの流れについても明らかになった。まず東京 湾, 瀬戸内海, 有明海などの内湾域に限らず, 九州西岸, 四国以北の太平洋および北海道といった外洋に面した海 岸においても, 日本ライターが9割以上を占めた。また 沖縄県与那国島や小笠原諸島のような大量消費地加ら遠 い離島海岸でむ日本ライターが 3 割以上を占めた。さら にその流出地を詳細に見ると, 漂着地の周辺市町村だけ ではなく，県を越えた地域からの漂着屯多く見られた。 これより日本起源のごみむ大量に日本周辺の海洋に流出 していることが推察される。またコアホウドリが北太平 洋上で誤食したライターの流出国構成割合 ${ }^{2}$ (は, 四国以 北の太平洋沿岸や、沖縄方面で収集されたライタ一の構 成割合之全く異なり，小笠原諸島の構成割合と近い。 よって日本を起源としたごみは，日本沿岸だけでなく広 く太平洋上にも漂流していることが危惧される。今後, ごみによる海洋污染問題を議論するためには，国内を含 めた東アジア圈といった広域での発生源対策が早急に必 要であるといえる。

さらに, 1998 年の鹿児島県薩摩半島西岸のごみ大量 漂着時 ${ }^{77}$ 以降, $1999 \sim 2003$ 年にかけて行った九州西岸 での調査 ${ }^{2}$ や今回の結果からは, 当時と同じような流出 地（中国華南・華東, 台湾) 加らの大量漂着は観測され ていない。このように指標アイテムを用いた継続調査で は, 単なる数量だけではなく, 流出地情報を含めた経年 变化を把握することもできる。またライターといった単 一アイテムを全国の海岸から同時に収集することにより， 廃油ボールの付着率から全国の海岸における廃油ボール の漂着分布や, 生物付着率や損傷度から長期間浮遊物の 漂着の有無についても検討することができ, 海洋ごみに よる海岸の污染状況を把握することもできる。さらに今 回の結果は, 中国㧍よび韓国を起源とする越境ごみの監 視には島根県から福井県の日本海中央部の海岸, 台湾を 起源とする越境ごみの監視には沖縄県八重山地方, さら には太平洋に与える日本を含めた東アジア圈を起源とす る越境ごみの監視には，小笠原諸島が重要な役割を担う ということを示している。今後, 東アジア圏での海洋ご みのモニタリングを開始するにあたっては，このような 地域で重点的に監視することが望まれる。

以上より, 流出地情報を持つ単一漂着物を指標とした 海洋ごみのモニタリング手法は, 流出起源や漂着ルート 
の解明および漂着物による海岸の污染度を知る有益な手 法の一つであるといえる。以下にライターを指標とした モニタリング手法の特徵をまとめる。

(1) 小型で目立つことから, 全国の漂着物収集家等に 依頼することにより，短期間に数量，範囲とも十 分な試料を得ることができる。

(2) 全国調査とすることにより, 流出地から見た漂着 地の特性を得ることができ, 海洋ごみの流れを知 ることができる。

(3) 多品目調査と同じ, もしくはそれ以上の詳細な結 果を得ることができる

(4) 調查を継続することにより, 海洋ごみの流れに関 する経年変化を把握することができる。

（5）付着物より，収集海岸の漂着物による污染状況を 把握することができる。

(6) 構成割合から海洋ごみのモニタリング地点の選定 に関する情報を得ることができる。

今後は,この手法が東アジア圈といった広域で利用さ れ, 海洋ごみ対策の検討に利用されることを期待したい。

\section{[謝 辞]}

今回の第一期調査には, 石井 忠, 石川慎也, 伊 藤実, 金子エミ, 兼松方彦, 川崎ミキ才, 久野幸 子, 久保公子, 久保田信, 倉重加代, 京馬伸子, 小 林真樹, 佐藤正平, 竹田正義, 田中幸雄, 中司光子, 中西弘樹, 橋川篤子, 林 重雄, 牧野伸一, 松本敏
郎, 吉井信秋氏の協力を頂いた。ここに厚くお礼申 し上げる。なお本研究は, 平成 15 年度廃裹物学会 先導型研究費によって行われたものである。

\section{参考文献}

1) 山口晴幸: 外国から漂着するゴミによる海岸污染, 土 木学会誌, 第 83 巻, 第 3 号, pp. 60-62 (1998)

2 ) 藤枝繁: ディスポーザブルライターを指標とした海岸 漂着散乱ゴミの流出地推定, 漂着物学会誌, 第 1 巻, pp. $13-20$ (2003)

3) JEAN・クリーンアップ全国事務局：クリーンアップ. キャンペーン 2003 報告書, JEAN・クリーンアップ全 国事務局, pp. 40-55（2004）

4) 東山高等学校地学部：琴引浜に漂着するレジンペレッ ト, ライター, タバコの吸い殼について, 東山学園研 究紀要, 第 41 巻, pp. 19-39（1996）

5 ) C. A. Ribic: Use of Indicator Items to Monitor Marine Debris on a New Jersey Beach from 1991 to 1996, Marine Pollution Bulletin, Vol.36, pp. 887 891 (1998)

6) 東山高等学校地学部, 安松貞夫：日本海の環境污染を 海岸漂着物から考える, 地学教育と科学運動, 第 29 号, pp. $27-34$ (1998)

7 ) 藤枝 繁：1998 年 8 月鹿児島県薩摩半島沿岸に漂着し た大量ゴミの実態, 水産海洋研究, 第 63 巻, 第 2 号, pp. 68-76 (1999)

8 ）安松貞夫：漂着物による污染の現状, 二丈町姉子の浜 の鳴き砂保全活用調查報告書, 㮩日本ナショナルトラ スト, pp. $29-40$ (2000) 


\title{
Monitoring Marine Debris Using Disposable Lighters as an Indicator
}

\author{
Shigeru Fujieda*, Azusa Kojima** and Haruyuki Kanehiro*** \\ * Kagoshima University, Fac. of Fisheries \\ ** JEAN Cleanup Japan Office \\ *** Tokyo University of Marine Technology, Fac. of Marine Science \\ ' Correspondence should be addressed to Shigeru Fujieda : \\ Kagoshima University, Fac. of Fisheries \\ (50-20 Shimoarata4, Kagoshima-city, Kagoshima, 890-0056 Japan)
}

\begin{abstract}
Sources of marine debris that had drifted ashore in Japan were investigated using a specific indicator item. Disposable lighters were chosen as an indicator because the discharge area and location can be distinguished from the print on the surface of the tank and the punch mark on the bottom. In one year, 6609 lighters were collected from 120 beaches by nation-wide beach combers. Chinese lighters accounted for over half of those collected in coastal areas from Yonaguni Island (Okinawa) to Yaku Island (Kagoshima), and they accounted for about $10-20 \%$ of the lighters found along the coast of the Japan Sea from Kyushu to Yamagata. Korean lighters accounted for $10 \%$ in the coastal areas from Okinawa to west of Kyushu, but accounted for over half of the lighters found on the coast of the Japan Sea from Shimane to Fukui. Japanese lighters almost filled in the coasts of Seto Inland Sea and Tokyo Bay, and at the Pacific coast of the north from Shikoku. Lighters from other countries were found in the coastal areas of Zhejiang and Guangdong (in China), and across Taiwan and Korea. By pinpointing one item various connections could be made between discharge and flow.
\end{abstract}

Key words : lighter, marine debris, plastics, monitoring, source 